Int. J. Dev. Biol. 64: 7-19 (2020)

https://doi.org/10.1387/ijdb.190166ks

\title{
Developmental biology of dispersed pollen grains
}

\author{
KUNDARANAHALLI R. SHIVANNA ${ }^{*, 1}$ and RAJESH TANDON ${ }^{*, 2}$ \\ ${ }^{1}$ Ashoka Trust for Research in Ecology and the Environment, Bengaluru, India and \\ ${ }^{2}$ Department of Botany, University of Delhi, Delhi, India
}

\begin{abstract}
Professor Panchanan Maheshwari served as Professor and Head of the Department of Botany, University of Delhi, from 1950 to 1966 and built an internationally reputed School of integrated plant embryology. Studies carried out during and after Maheshwari's period from this School have enormously advanced our knowledge of the structural, developmental and functional aspects of embryological processes. This review covers studies carried out at the Delhi School on the developmental biology of dispersed pollen grains which operate from pollen dispersal from the anthers until pollen tubes discharge the male gametes in the embryo sac for fertilization. These events include pollen viability and vigour, pollen germination and pollen tube growth, structural details of the pistil relevant to pollen function, pollination and pollen-pistil interaction.
\end{abstract}

KEY WORDS: ovule pollination, pollen grain, pollen germination, pollen-pistil interaction, pollen viability, pollination

\section{Introduction}

Professor Panchanan Maheshwari FRS (Fig. 1), served as the Head, Department of Botany, University of Delhi, from 1950 to1966, and built an internationally reputed school of integrated plant embryology. Initial studies from this School largely covered traditional methods to study developmental events associated with embryological processes by using fixed and wax-embedded sectioned materials at the bright-field microscopic level. However, Maheshwari introduced the techniques of plant tissue culture in the Department during 1960 s for the first time in the country and widened the scope of embryological studies to cover experimental aspects also. These integrated studies started yielding valuable information on the developmental and functional aspects of tissues and organs involved in embryological processes - pollen, ovule, embryo, endosperm and seed. Subsequent Heads of the Department, especially Professor B.M. Johri and Professor H.Y. Mohan Ram continued the legacy to sustain and encourage such integrated studies. Apart from establishing many firsts in several areas, these studies have generated new knowledge on the developmental biology of various embryological events. In recent years these studies are being integrated with molecular biology and genetics also. A discussion on all these areas is beyond the scope of this review. Many of these aspects are covered by Shivanna and Mohan Ram (2005). This review covers only some aspects of the developmental biology of pollen from Delhi School.
Pollen grains represent male partners in sexual reproduction of seed plants (gymnosperms and angiosperms/flowering plants). Their intrinsic function is to discharge male gametes near the female gamete for fertilization by passing through several sequential steps. In flowering plants pollen grains develop in the anthers (developmental phase); following their dispersal from the anthers, pollen grains remain as independent functional units (free-dispersed phase) until they land on the stigma through pollination. After landing onto the stigma, pollen grains interact with the stigmatic tissues of the pistil leading to their germination and the resulting pollen tube from each pollen grain grows through the tissues of the stigma and style, and eventually enters the embryo sac developed inside the ovules located in the ovary (pollen-pistil interaction phase). After entering the embryo sac, pollen tube discharges the two male gametes for fertilization, thus completing its function. The developmental events of the dispersed pollen grains - pollen viability and vigour, pollen germination and pollen tube growth (both in vitro and in vivo ), structural details of the pistil relevant to pollen function, pollination and pollenpistil interaction, are covered here. A general account on these aspects are available in many reviews and books (Stanley and Linskens 1974, Shivanna and Johri 1985, Faegri and van der Pijl 1979, Kearns and Inouye 1993, Roubik 1995, Dafni et al., 2000, Herrera and Pellmyr 2002, Shivanna 2003, Higashiyama and

Abbreviations used in this paper: DAPI, 4',6-diamidino-2-phenylindole stain

\footnotetext{
*Address correspondence to: Kundaranahalli R. Shivanna. Ashoka Trust for Research in Ecology and the Environment, Srirampura, Jakkur Post, Bengaluru 560 064, India. Tel: 91 9449543848. Fax: 9180 23530070. E-mail: shivannakr40@ gmail.com - (D) https://orcid.org/0000-0003-0944-2801 or

Rajesh Tandon. Department of Botany, University of Delhi, Delhi 110 007, India. Tel: 91 9811998867. E-mail: tandon.raj@gmail.com

(D) https://orcid.org/0000-0003-3318-5956
}

Submitted: 4 July, 2019; Accepted: 19 August, 2019.

ISSN: Online 1696-3547, Print 0214-6282 
Hamamura 2008, Kawashima and Berger 2011, Willmer 2011, Mizuta and Higashiyama 2018).

\section{Free-dispersed phase of pollen}

The free-dispersed phase covers the events from the time pollen are shed from the anther until they land on the stigma. During this phase, pollen grains act as independent functional units responding to environmental variables. Pollen grains of a majority of the species are shed under desiccated condition (with the moisture content generally $<20 \%$ ); however, pollen grains of Poaceae (grasses) are shed under more hydrated condition (ca 50\% moisture). In about $70 \%$ of the species, pollen grains are shed in 2-celled condition, represented by a large vegetative cell with an internalized generative cell. In the remaining $30 \%$ of the species, pollen grains are shed in 3-celled condition containing a vegetative cell and the two male gametes formed by the division of the generative cell (Fig. 2). Although pollen grains are much simpler than the seeds, both of them are comparable physiologically and functionally -- both are desiccated and dormant systems, and represent the units of dispersal and gene flow.

\section{Pollen viability and vigour}

Pollen grains remain viable (i.e. able to perform their function of delivering functional male gametes to the embryo sac) after dispersal for varying periods ranging from as low as 30 min (many cereals) to several weeks. The prevailing environmental conditions, particularly the temperature and humidity, affect the period of maintenance of viability. Lower temperature and humidity prolong the viability period while higher temperature and humidity reduce

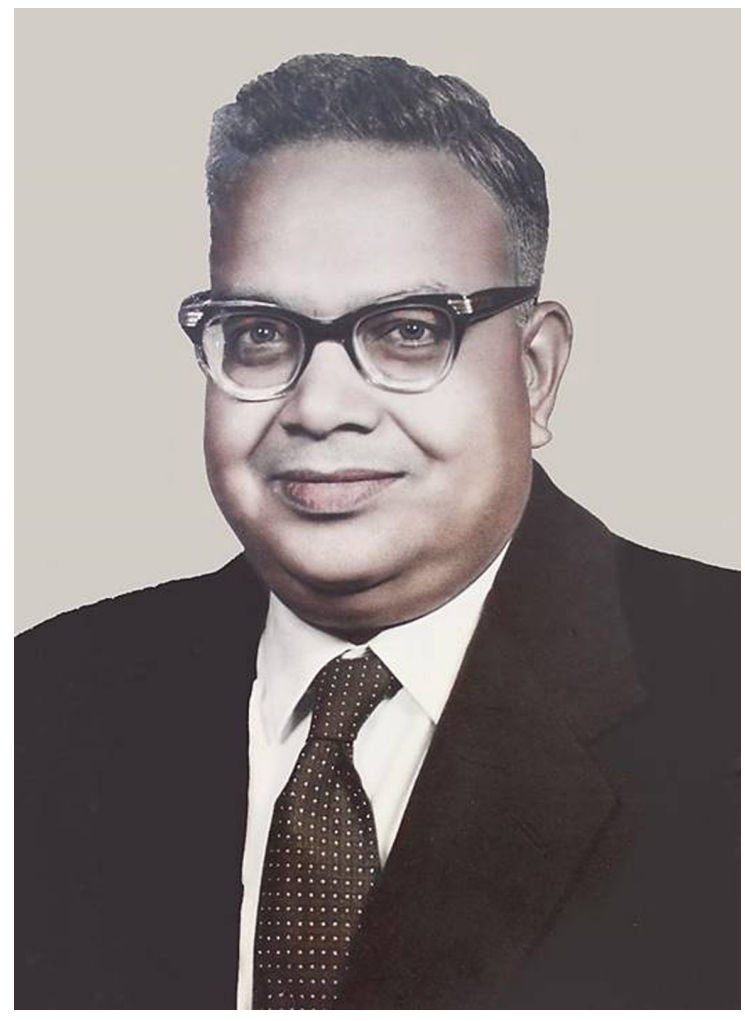

Fig. 1. Professor Panchanan Maheshwari FRS (1920-1966).

\section{Induction of pollen haploids}

Haploids are sporophytic plants with gametophytic chromosome number. They are of great importance in plant breeding programme. By doubling the chromosome number of haploids through colchicine treatment, a pure homozygous line (doubled haploid) can be obtained at one step. Otherwise it requires 7-9 generations of repeated selfing to get reasonably homozygous diploids that can be used in the breeding programme. However, since their discovery in 1920s, haploids remained a rare and chance factor in nature, and did not have much impact in the breeding programme. There was a great need for development of a method for experimental induction of haploids. Successful induction of haploids in cultured anthers by the Delhi School (Guha and Maheshwari 1964, 1966, see also Maheshwari et al., 1980) was a significant breakthrough in raising haploids directly from microspores. Apart from demonstrating the totipotency of pollen developing into a whole haploid plant, the discovery opened up a novel route of plant development. Subsequently the technique of anther and microspore culture for induction of haploids has been refined and extended to hundreds of species around the world and has been effectively used in developing new varieties in several crop species.

it. However, pollen grains of many species can withstand high temperature. For example, pollen grains of Petunia and Nicotiana (2-celled) can withstand even $75 \mathrm{C}$ for up to $12 \mathrm{~h}$ and set seeds, but similarly treated pollen grains of Brassica (3-celled) fail to set seeds after exposure to 75 C (Rao et al., 1992, 1995).

The factors responsible for loss of viability were not clear until the 1970s. The prevailing hypothesis explained loss of viability as a result of the deficiency of respiratory substrates and/or inactivation of enzymes and growth hormones. However, there was no direct evidence for this concept. Experimental studies by the Delhi School showed for the first time that the loss of pollen viability is directly associated with irreversible loss of plasma membrane integrity. (Shivanna and Heslop-Harrison 1981, Heslop-Harrison et al., 1984, Jain and Shivanna 1987a,b, 1989). Studies by Shivanna and Heslop-Harrison (1981) on the pollen grains of a number of species showed that the ability of pollen grains to germinate was invariably associated with the retention of plasma membrane integrity, as revealed by the fluorochromatic reaction test. Subsequent studies on pollen grains of Crotalaria retusa stored under different organic solvents substantiated the role of membrane phospholipids in maintaining pollen viability (Mishra and Shivanna 1982, Jain and Shivanna 1987a,b, 1989, 1990). Pollen grains stored in organic solvents, which maintained viability, showed very little leaching of sugars, free amino acids and phospholipids into the solvents (Jain and Shivanna 1987a, b), whereas the solvents which did not retain viability resulted in extensive leaching of these components. Thus, organic solvents favourable for storage do not remove membrane phospholipids; and consequently do not permit leakage of cytoplasmic components and maintain pollen viability.

Quantitative analysis of phospholipids in pollen grains of Crotalaria stored under different conditions also supported the relationship between retention of membrane integrity and maintenance of pollen viability (Jain and Shivanna 1989). Irrespective of the storage conditions, there was a positive and significant correlation between the loss of membrane integrity (indicated by the reduction in total and individual phospholipids, particularly phosphotidyl choline) in the stored pollen and loss of pollen viability. In the light 
of these studies, deficiency of respiratory substrates or inactivation of enzymes/growth substances as causal factors for the loss of pollen viability is no more tenable.

Another area of dispersed phase of pollen highlighted by Delhi School has been on the importance of pollen vigour (the speed of germination and the rate of pollen tube growth). Seed vigour and its loss before the loss of germinability was well established in assessing the quality of seeds since long (see Priestley, 1986). Although pollen vigour has been implicated as a component of pollen-pistil interaction (Mulcahy 1979, see Shivanna 2003), there were hardly any studies assessing the quality of pollen grains based on vigour. Unlike seeds which take many days for germination, pollen grains generally germinate within an hour and this may be a reason for not considering vigour as a factor during germination by early investigators. Our detailed studies have shown that vigour is also an important criteria in assessing the quality of pollen (Shivanna and Cresti 1989, Shivanna et al., 1991a,b). Pollen vigour is important, particularly in assessing the quality of aged and stored pollen, as the loss of vigour takes place before the loss of viability. We have assessed pollen vigour using in vitro germination as well as in vivo pollination tests. Pollen grains of several species were exposed to high temperature and/or high humidity conditions for varying periods, which are known to affect pollen viability, and cultured; subsequently the cultures were scored for viability and vigour. High temperature and high humidity applied together affected the vigour much before viability. For example in Nicotiana tabacum, fresh pollen reached maximum germination in $2 \mathrm{~h}$ after culture, whereas pollen exposed to high humidity at $38^{\circ} \mathrm{C}$ took 4 $\mathrm{h}$ to reach maximum germination. Pollen tube length recorded in stressed pollen was consistently short throughout the germination period. Even storage stress affected the vigour of the pollen much before viability in Crotalaria retusa (Jain and Shivanna 1989) and species of Nicotiana and Agave (Shivanna et al., 1991a). Loss of pollen vigour before viability was confirmed under in vivoconditions also (Shivanna et al., 1991b).

\section{Pollen germination and pollen tube growth}

Pollen germination is the first developmental event of the pollen in fulfilling its main function of fertilization. It involves hydration of pollen followed by the emergence of pollen tube and its growth through the tissues of the stigma and style until it enters the embryo sac. Pollen tube growth is confined to the tip. The main developmental activities during pollen germination and pollen tube growth are the synthesis of enormous amount of pollen wall components and their deposition at the growing tip of the pollen tube, and the movement of the vegetative nucleus and the generative cell/male gametes along the tip of the pollen tube. Pollen wall materials are synthesized in the dictyosomes; the membrane bound dictyosomederived vesicles containing pollen wall components move toward the tip of the tube along the microfilament pathway and fuse with the plasma membrane to supply membrane and wall components to the growing tip (see Mascarenhas 1993, Shivanna 2003). In 2 -celled pollen, the division of the generative cell to give rise to the two male gametes occurs during the initial period of growth of the pollen tube in the pistil.

Pollen grains of a large number of species, particularly of 2-celled pollen systems, can be germinated in vitro using rather a simple nutrient medium containing a carbohydrate source, generally sucrose, along with boron and calcium. As the physiological and biochemical studies associated with pollen germination and pollen tube growth are difficult to perform under in vivo conditions, in vitro germination technique has been used extensively to study these aspects (Stanley and Linskens 1974, Shivanna and Rangaswamy 1992, Shivanna 2003, Shivanna and Tandon 2016). Studies on pollen germination from Delhi School cover a number of aspects. As pollen grains are desiccated systems, one of the primary requirements for their germination is hydration. It has been shown in a number of species that hydration in vapour phase achieved by exposing pollen grains to high humidity for about $30 \mathrm{~min}$ (controlled hydration) before culturing them in liquid or on a semi-solid medium improves in vitro germination (Shivanna and Heslop-Harrison 1981). Controlled hydration has been shown to facilitate plasma membrane restoration; in the absence of controlled hydration, plasma membrane is unable to restore its integrity thus allowing excessive leakage of metabolites from the cytoplasm (Jain and Shivanna 1989).

Studies from Delhi School have standardized the medium to achieve improved pollen germination and pollen tube growth in cultured pollen grains of several species. Generally, satisfactory germination is achieved in pollen grains of a large number of species on a medium containing around $10 \%$ sucrose. Many species, particularly of 3-celled pollen generally require higher sucrose concentration in the medium; however, the medium that induces good pollen germination is not satisfactory for tube growth. Brassica, which includes a number of important crop species, is a 3-celled pollen system. Although good pollen germination has been achieved in $20 \%$ sucrose medium, tube growth has been very

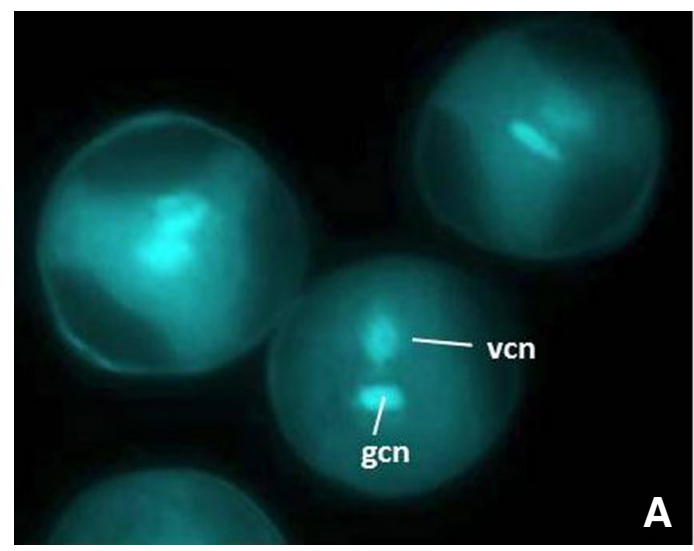

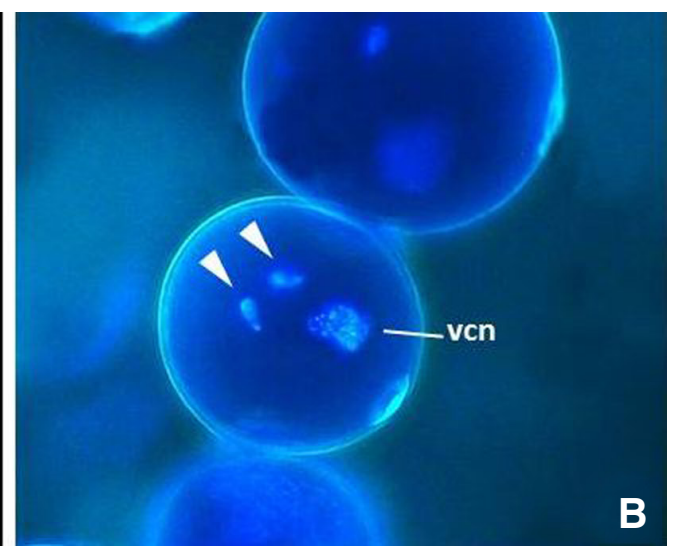

Fig. 2. Fluorescence micrographs of pollen grains stained with DAPI, a DNA fluorochrome. (A) Two-celled pollen grains of Tecomella undulata. Nucleus of the vegetative (vcn) and generative (gcn) cells are fluorescing. (B) A three-celled pollen of Cenchrus ciliaris; nuclei of the two male gamete (arrowheads) and diffuse vegetative cell nucleus (vcn) are clear. 
limited (Hodgkin 1983), indicating that high sucrose concentration needed for germination may not be suitable for tube growth. By using the media with lower sucrose concentrations, we could improve tube growth about three times when compared to $20 \%$ sucrose, although the extent of germination was reduced (Shivanna and Sawhney 1995). There was a need for media that permits good pollen germination as well as pollen tube growth to carry out routine pollen assays. Following a few earlier reports (Zhang and Croes 1982, Read et al., 1993) on the beneficial effects of high molecular weight polyethylene glycol (PEG) on pollen germination, we could manipulate the concentration of PEG and sucrose in pollen germination medium to achieve markedly enhanced pollen tube growth without reducing the extent of germination in Brassica (Shivanna and Sawhney 1995), chickpea (Shivanna et al., 1998) and oil palm (Tandon et al., 1999).

Both RNA and protein synthesis occur during pollen germination and pollen tube growth (Mascarenhas 1975, Ghosh and Shivanna 1983). In several systems, actinomycin D, an inhibitor of RNA synthesis, does not inhibit pollen germination as well as early tube growth, but cycloheximide, an inhibitor of protein synthesis, inhibits both pollen germination and pollen tube growth (Shivanna et al., 1974a, b, Ghosh and Shivanna 1983). Thus, RNAs stored in mature pollen are used in germination and early tube growth but fresh protein synthesis is required for continued tube growth. We showed for the first time that in Impatiens balsamina, a 2-celled system in which pollen grains germinate within a few minutes after culture, cycloheximide does not inhibit pollen germination and pollen tube growth but inhibits the division of the generative cell (Shivanna et al., 1974a). Generative cell division is not inhibited when the cycloheximide is added 90 min after culture. These studies showed that in Impatiens, pollen proteins required for germination and tube growth are synthesized before pollen shedding but proteins needed for generative cell division are synthesized during the first 90 min after culture. Subsequent studies confirmed our results and conclusions on Impatiens and showed that the same situation prevails in other pollen systems having a short lag phase (time taken for pollen tube emergence after culture) (Hoekstra and Bruinsma 1979, 1980).

\section{Pollen storage}

One of the barriers for hybridization has been temporal and/ or spatial isolation of the parent species. The potential parents to be hybridized may not flower at the same time or do not grow at the same place. The most effective technique to overcome such barriers is to store the pollen grains of the male parent in viable condition and use them for pollination when the female parent flowers. Pollen storage also eliminates the need to grow pollen parent continuously in the breeding programme and ensures the availability of pollen throughout the year for studies on various aspects of pollen biology particularly pollen allergy. A number of methods have been standardized over the years to store pollen grains of a range of species in viable conditions (Shivanna and Rangaswamy 1992, Shivanna 2003, Shivanna and Tandon 2014). Pollen of Poaceae which includes all the cereals was known, since long, to be an exception; they are shed under hydrated condition (ca 50\% moisture level) and lose viability within hours after shedding and are difficult to store even for a few days. Studies of Vasil from Delhi School as early as mid-1950s showed that pearl millet
(Pennisetum typhoideum) pollen was an exception amongst cereal pollen; they were reported to be viable for up to 100 days based on bursting of pollen or production of protuberances following their culture (see Johri and Vasil 1961), which is not considered as a valid test for viability. Studies on pollen storage of Pennisetumwere taken up by Delhi School again in 1980s (Chaudhury and Shivanna $1986,1987)$ to clarify earlier reports and compared the response with those of Secale cereale (a typical cereal pollen system). The results clearly showed that unlike Secale and other cereals, pollen of Pennisetum, although 3-celled, are shed under desiccated condition (ca $20 \%$ moisture level) similar to other 2-celled pollen systems. Our studies also showed that bursting of pollen or production of protuberances in vitro does not indicate viability. Using seed set data following pollination to assess viability we showed that pollen of $P$. typhoideum could be stored under subfreezing temperature for up to 200 days (Chaudhury and Shivanna 1986). Taking this lead, Hoekstra et al., (1989) carried out comparative biochemical studies between pollen of Pennisetum and Zea mays which is highly sensitive to desiccation, and showed that differential responses of pollen of these two species depended on the amount of sucrose present in the pollen; it was 4\% in Zea whereas it was $14 \%$ in Pennisetum. In recent years, pollen storage at ultra-low temperatures (in liquid nitrogen) has proved useful not only as a means of germplasm conservation but also to prolong the storage period. We were successful in cryopreserving the oil palm pollen in collaboration with the National Bureau of Plant Genetic Resources (NBPGR), New Delhi. The stored pollen sample retained a significant amount of viability up to 8 years at the time of its previous assessment for viability (Tandon et al., 2007).

\section{Development of the pistil and pollen-pistil interaction}

The pistil, differentiated into the stigma, style and ovary, is unique to the flowering plants. Following pollination, pollen grains germinate on the stigma and the resulting pollen tubes grow through the tissues of the stigma and style before entering the ovule (Figs. 3, 4). This phase, referred to as pollen-pistil interaction, is a prerequisite for fertilization. Limited studies carried out around the world during 1950s and 1960s on pollen-pistil interaction have highlighted the role of the pistil in screening pollen grains; compatible pollen grains are recognized by the pistil facilitating their germination and tube growth whereas incompatible pollen grains are inhibited before they reach the ovary. These early studies stimulated further investigations on the pistil which are needed to understand the structural and functional details of pollen recognition and subsequent promotion or inhibition of pollen germination or tube growth. Thus, pollen-pistil interaction plays a critical role in sexual reproduction in flowering plants.

Only limited studies were carried out at Delhi School until 1960s on the structural details on the pistil of some members of Liliaceae and Amaryllidaceae (Vasil and Johri 1964, Johri 1966 a, b) by employing microtomy technique used for embryological studies. Later, while working at Professor Linskens' Laboratory at Nijmegen, the Netherlands, Konar conducted electron microscopic studies on the pistil of Petunia hybrida (Konar and Linskens (1966 a, b). Apart from documenting the cellular details of the pistil and secretion of the stigmatic exudate, he showed that the exudate in Petunia is lipoidal. However, these interesting studies were not continued at Delhi School for some time. Studies on these lines were taken up 


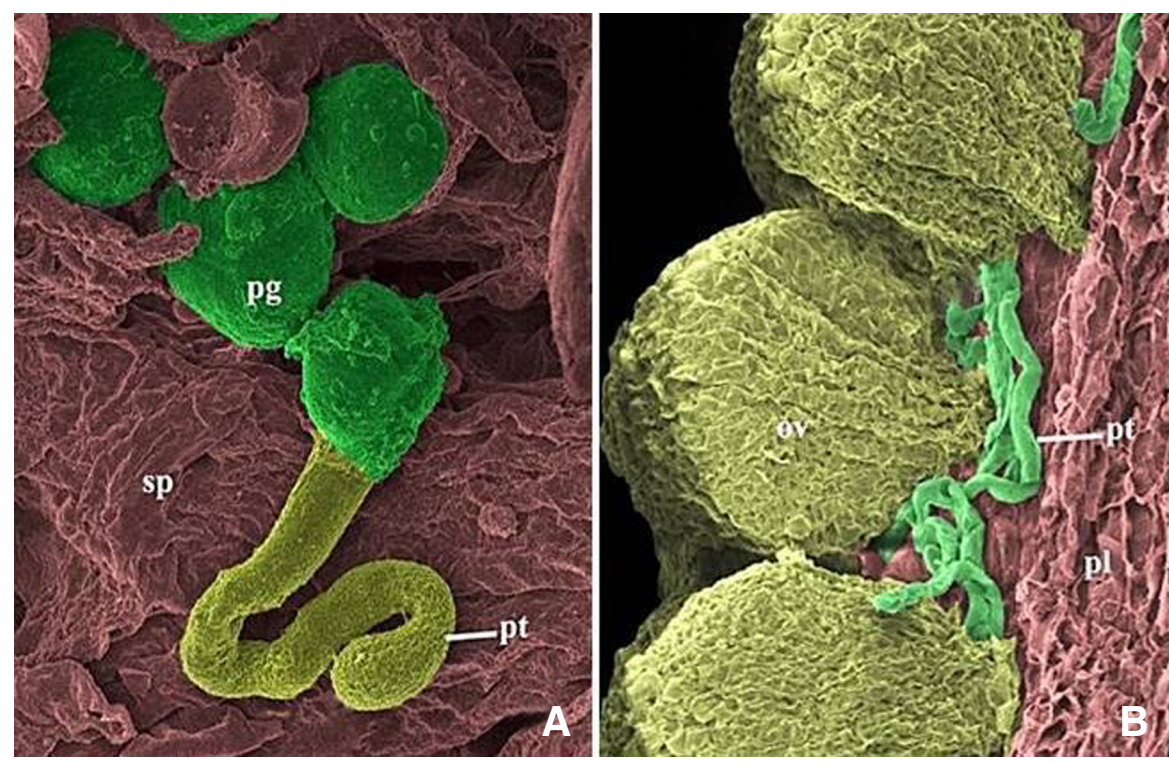

Fig. 3. Scanning electron micrographs of pollinated pistil of Tecomella undulata. (A) Stigma surface (sp) showing the stigma loaded with pollen grain (pg) with the pollen tube (pt). (B) Pollen tubes (pt) around the ovules (ov) inside the ovary, pl: placenta. (Images: Vineet K Singh). on the stigma at the time of pollination) and the cellular features of the receptive surface of the stigma. This classification of stigmas is being followed even now throughout the world. The studies also brought out broad correlations between the characteristics of the stigma and the cytology of the pollen and the genetics of self-incompatibility (SI). More importantly these studies showed that irrespective of its morphological variations, the stigma surface invariably contains extracellular materials (ECM) containing proteins, glycoproteins and a number of other components, comparable to those present in the pollen wall. In the dry type of the stigma the ECM is present in the form of a thin layer, termed pellicle, on the surface of the stigma, and in the wet-type it is present as a part of the exudate. Pollen grains, following pollination, release pollen wall components onto the stigma surface which act as 'visiting cards' of pollen; they come in contact with the ECM of the stigma which is able to read the 'visiting cards' and activate the processes to facilitate or inhibit pollen germination and pollen tube again in 1970s and have continued vigorously until now. One of the requirements to understand pollen recognition by the pistil is to understand the details of recognition factors present in the pollen grains and the pistil. During 1970s Professor Heslop-Harrison and his associates at the Royal Botanic Gardens, Kew, London, established that pollen grain wall invariably contains extracellular material (ECM) containing proteins, carbohydrates and many other substances (Knox and Heslop-Harrison 1969, Heslop-Harrison 1975, Heslop-Harrion et al., 1974, Knox et al., 1975). These studies also showed that ECM of the pollen wall contain recognition factors and plays an active role in pollen germination and pollen tube growth. However, studies on these lines were lacking on the pistil side.

Shivanna, while working in Professor Heslop-Harrison's laboratory at the Royal Botanic Gardens, Kew carried out one of the most comprehensive studies on the stigma, the recipient of the pollen grains (Heslop-Harrison and Shivanna 1977). He screened the stigmas of over 1000 species covering all prevailing variations and classified them into different groups based on the presence or absence of the stigmatic exudate (an aqueous or lipidic secretion out to be a classic, and stimulated further studies on the pistil and pollen-pistil interaction around the world. Subsequent studies from the Delhi School as well as by others have shown that the presence of ECM on the stigma surface is a general feature of all the stigmas investigated so far without exception. When the ECM components are disrupted by treating the stigma with a detergent or pronase enzyme, pollen germination and/or pollen tube entry into the stigma are inhibited (Shivanna et al., 1978). Subsequent studies have characterized the role of pollen wall and stigma surface components in pollen recognition in several systems (see Shivanna and Johri 1985, Shivanna 2003).

The style through which the pollen tube grows is of two types, solid and hollow. Studies of Delhi School have covered several solid as well as hollow-styled species (Fig. 4). In solid style, there is a core of transmitting tissue connecting the stigma with the ovary. The cells of the transmitting tissue are separated by massive intercellular spaces filled with ECM secreted by these cells (Shivanna and Sastri 1981, Ghosh and Shivanna 1984, Tandon et al., 2001a, Shivanna 2003, Shivanna and Mohan Ram 2005). growth depending on the nature of the pollen. This paper turned
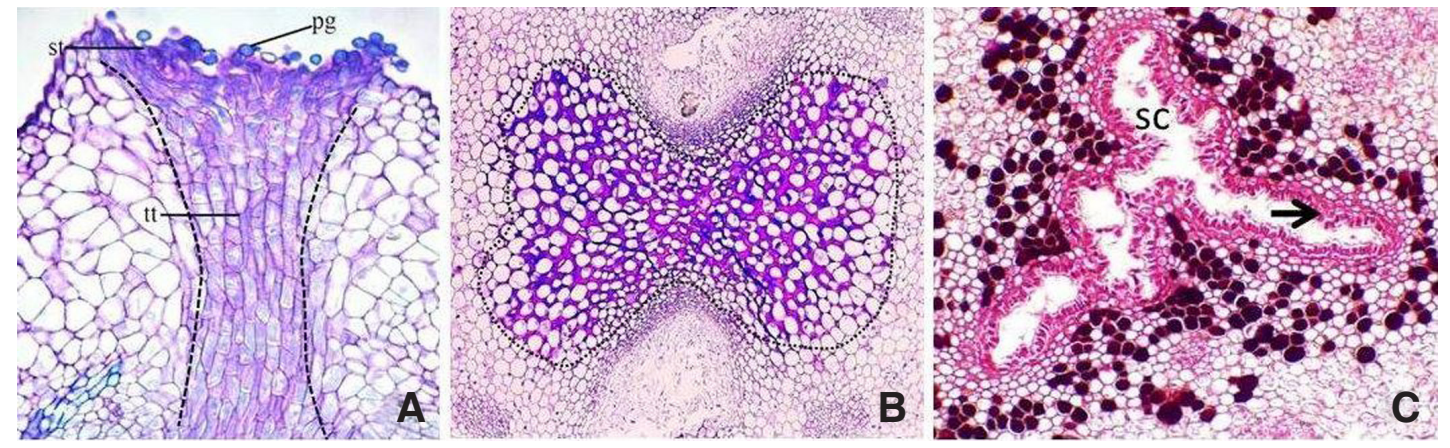

Fig. 4. Structural details of the style. (A) Longitudinal section of a pollinated pistil of Salvadora oleoides showing the stigma and upper part of the solid style. The cells of the transmitting tissue (tt, indicated within dotted lines) are densely cytoplasmic and are arranged as vertical files of elongated cells. (B) A cross section of the solid style of Oroxylum indicum. The intercellular spaces in the transmitting tissue (central part indicated by dotted line) are filled with mucilagenous secretion rich in polysaccharides. (C) Cross section through a hollow style of oil palm. The stylar canal (sc) is lined with glandular canal cells (arrow). 

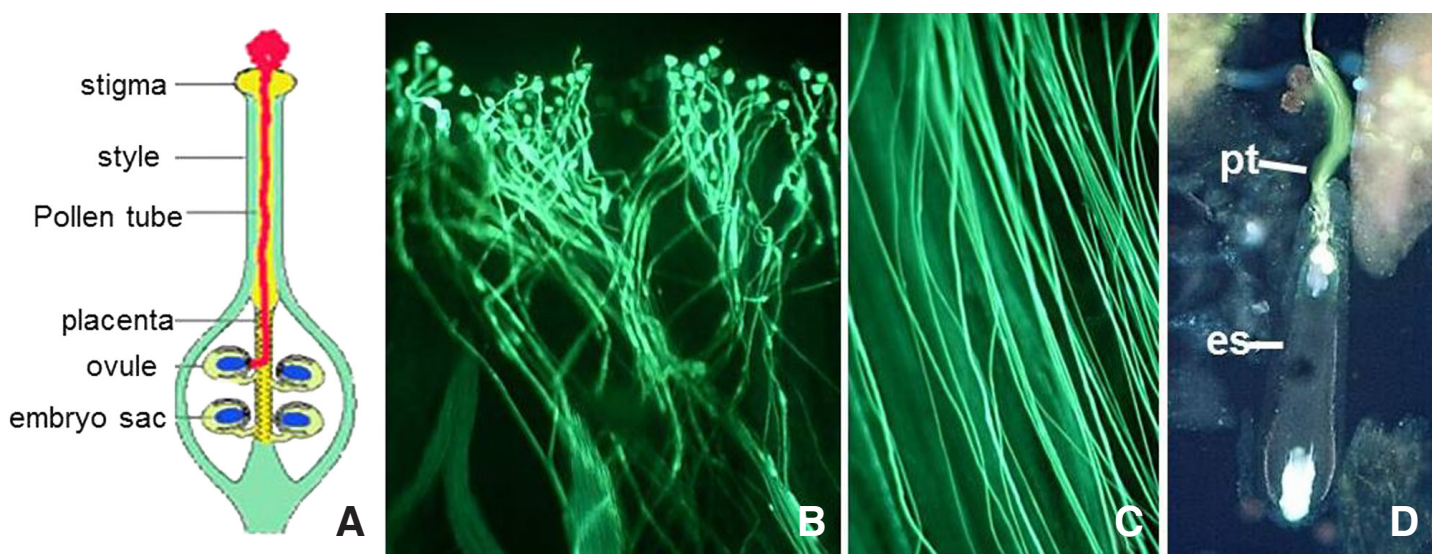

Fig. 5. Pollen-pistil interaction phase of pollen. (A) Diagrammatic representation to show the path of pollen tube growth in the pistil. B-D. Fluorescent micrographs of aniline blue stained pollinated pistils to show pollen germination on the stigma (B), pollen tube growth in the style (C) and pollen tube entry into the ovule (D). es, embryo sac; pt, pollen tube. (B-D, After Shivanna and Tandon 2014).

In hollow-styles the glandular canal cells surrounding the stylar canal secrete ECM which cover the inner tangential walls of the canal cells or fill the stylar canal. Pollen tubes invariably grow through the intercellular spaces filled with ECM (in solid styles) or on the surface of the canal cells (in hollow styles). Thus growing pollen tubes invariably come in contact with the ECM of the stigma and style and there is a continuous dialogue between the ECM components of the pistil and pollen (Fig. 5).

Most of our knowledge on the structural details of the pistil of legumes including several economically important species such as pigeon pea, cowpea, chickpea, mungbean, and groundnut has come from Delhi School (Ghosh and Shivanna 1982, Malti and Shivanna 1983, 1984, Lakshmi and Shivanna 1984, see Shivanna and Owens 1989). The stigma in all the studied species is of the wet-papillate type, although the amount of the exudate is highly variable. The structure of the style in legumes turned out to be unusual; the stigma and the style just below the stigma are of the solid type but further down an irregular canal appears amidst central part of the transmitting tissue by cellular degeneration; the canal gradually becomes larger further down and the style becomes typically hollow bordered by glandular canal cells. Thus, the upper part of the stylar canal in legumes develops as a result of degeneration of the cells of the transmitting tissue and the lower part appears to be the extension of the ovarian cavity. These were the first reports of such a transition from the solid to hollow style in flowering plants; this situation is unlike the typical hollow-styled systems in which stylar canal is continuous and connects the stigma to the ovarian cavity. Subsequent studies in other species of legumes by other investigators have confirmed the reports of Delhi School (see Shivanna 2003).

\section{Pollination ecology}

In flowering plants, pollination refers to the transfer of pollen grains from the anther to the stigma. This is a prerequisite for fertilization and fruit and seed-set. Over $90 \%$ of the flowering plants use a range of animals to achieve pollination; the remaining use wind or water for this purpose. Human-induced environmental changes - habitat degradation, overexploitation of bioresources and climate change -- have pushed a large number of species to the verge of extinction precipitating 'the sixth mass extinction crisis' (Ceballos et al., 2017; Davis et al., 2018; Shivanna 2019). Massive biodiversity loss is threatening the essential ecosystem services that affect human welfare. Effective management and conservation of our biodiversity has become a major challenge in the coming decades. Pollination is one of the most critical ecoservices which is critical for sustenance of plant diversity in their natural habitats as well as of crop productivity in agricultural habitats. Extensive studies carried out in many Western countries have shown that environmental changes in recent decades have markedly reduced the density and diversity of pollinators in natural and agricultural habitats affecting pollination services of wild as well as crop species (Biesmeijer et al., 2006, Holden 2006, Burkle et al., 2013). The world is facing 'global pollinator crisis'; unless suitable measures are taken to mitigate this crisis, sustenance of biodiversity and food and nutritional security of humans are threatened. Many international initiatives are being undertaken to study pollinators and pollination services to mitigate pollinator crisis (IPBES 2016). However, in India pollination has been completely neglected and very few laboratories in the country are working in this important field. Although India is a megadiversity country with rich biodiversity and a large proportion of endemic elements, we do not know anything about what is happening to our pollinators and pollination services. We do not have even the baseline data on pollination ecology of most of our wild and even cultivated species. Such studies are very important for effective management of our biodiversity particularly the endangered and endemic species and sustainable utilization of economically important species.

Delhi School has extended studies on pollination since 1990s on a wide range of species covering both wild and economically important plants. One of the major limitations of earlier studies on pollination ecology around the world has been that most of them have not distinguished pollinators from floral visitors. All floral visitors need not be the pollinators; some of them may be the pollen and/or nectar robbers without effecting pollination and some may be the predators on other floral visitors. Confirmation of a floral visitor as a pollinator has to be on the basis of pollen transfer to the stigma following the visit of the potential pollinator to virgin flowers. But this takes a lot of time and efforts with the result very few investigators carry out such detailed studies, and consider all floral visitors as pollinators. All studies of Delhi 
School on pollination ecology have confirmed pollinators on the basis of pollen transfer to the stigmas of virgin flowers.

\section{Gum and gum-resin yielding species}

Detailed studies have been made on pollination ecology of several gum and gum-resin yielding species such as Commiphora wightii (the source of guggul), Acacia senegal (the source of gum arabic), Sterculia urens (the source of gum karaya), Boswellia serrata (the source of salai guggul) and Azadirachta indica (the source of neem gum), on which no information was available.

Most of the natural populations of Commiphora wightii turned out to be made up of largely female plants with only a few or no males (Gupta et al., 1996). However, all female plants set seeds normally irrespective of the presence or absence of male plants in the population. This realization led to further studies on reproductive biology of this species. There was no natural pollination at all; even manual pollinations did not result in normal pollen germination and pollen tube growth. Pollen grains failed to germinate or a few pollen tubes that emerged failed to grow through the style due to lack of intercellular spaces, a characteristic feature of all other species so far studied. Thus, there was no fertilization and the seed set turned out to be the result of obligate apomixis (seed development without fertilization) (Gupta et al., 1996, 1998). Detailed developmental studies revealed that although embryo sac differentiates in the ovule, the egg degenerates and multiple embryos develop from the surrounding nucellar cells. Unlike many other apomictic species which require pollination stimulus and endosperm development as a result of pseudogamy (fusion of one of the sperms with the central cell to give rise to the endosperm and the degeneration of the other sperm without fusion with the egg cell), in C. wightii, apomictic embryo development is independent of pollination stimulus and endosperm development is non-pseudogamous. This species provides a good system to study the molecular basis of apomixis.

Acacia senegal has a wet, saucer-shaped stigma and the pollen grains are shed in the form of a polyad containing 16 pollen grains (Tandon et al., 2001b). Although the blossom attracts a number of insects, the Giant Asian honey bee, Apis dorsata is the main pollinator. The species is self-incompatible and thus an outbreeder. However, unlike most other self-incompatible species in which pollen tubes are inhibited on the stigma or in the style, Acacias usually show delayed inhibition in the nucellar region of the ovule; however, self-pollen tubes in $A$. senegal are inhibited after entering the embryo sac. Under natural conditions, fruit set is very low $(0.36 \%)$. This is due to limitation of cross-pollination; fruit set can be increased up to $30 \%$ by manual cross-pollination.

The flowers of Butea monosperma (Flame of the Forest) are typically ornithophilous (bird pollinated) with nectar as the major reward (Tandon et al., 2003). Although the flowers are known to attract as many as seven species of birds, in our study only the purple sunbird (Nectarinia asiatica) was found to be the effective pollinator; most of the other birds robbed the nectar but did not bring about pollination. Interestingly, the three-stripped squirrel (Funambulus tristriatus) also turned out to be an effective pollinator. This was the first confirmed report of squirrel pollination from India.

Sterculia urens exhibits interesting floral sexuality (Sunnichan et al., 2004). Morphologically the trees are andromonoecious producing a large number of male and a limited number of bisexual flowers with normally looking anthers. However, all the pollen grains produced in bisexual flowers are sterile; thus, functionally the sexuality in this species is cryptic monoecy (producing functional male and female flowers on the same plant). Apis indica is the only pollinator for this species. Interestingly, the anthers produced in bisexual flowers serve as pollinators' attractants; pollinators fail to visit bisexual flowers from which anthers are removed. The species also shows delayed self-incompatibility and manifests after the self-pollen tubes enter the ovary. Fruit set under natural condition is poor and varies between trees (0.7-3.2\%); low fruit set is the result of pollination as well as resource limitation. Boswellia serrata offered both nectar and pollen as rewards to the floral visitors (Sunnichan et al., 2005). Although flowers attracted a few insect species only Apis dorsata and $A$. cerana were the effective pollinators. This species is also self-incompatibile; inhibition of self-pollen tubes occurring soon after entering the stigma region.

Commiphora, Sterculiaand Boswellia have become endangered due to overexploitation. This is largely because of the crude methods used for tapping. Delhi School developed a refined tapping method that causes very limited injury along with the application of ethephon, an eco-friendly plant growth regulator (Nair et al., 1995). This method apart from early wound healing, also increased gum yield significantly. This simple and non-destructive method has to be standardized for commercial application and tapping so that the plants can sustain tapping for a number of years. Also, many of these species are difficult to propagate through cuttings/ seeds. We have also standardized micropropagation protocol for Sterculia to produce a large number of plants for reforestation (Sunnichen et al., 1998).

\section{Other interesting/economically important species}

Studies on pollination biology on one of the most invasive alien weeds, Lantana camara was among the first to be carried out at the Department (Mathur and Mohan Ram 1978, Mohan Ram and Mathur 1984). The freshly opened flowers are yellow and offer pollen and nectar rewards to the pollinators. With age, the flowers change their colour first to orange, then to scarlet and finally to magenta. Thrips are the major pollinators. Pollination triggers the colour change. Even pollen extracts are effective in changing floral colour. Although older flowers are retained on the plant for many days, they do not offer rewards. Detailed observations revealed that pollinators visit only the fresh yellow flowers but not the older flowers. Subsequent studies have confirmed the above results of Lantana and have also extended such studies to many other systems (Gori 1983, Weiss 1991). Retention of non-rewarding flowers on the plant is an effective adaptation to increase the plant's attraction to pollinators from a distance, but when they come nearer the flowers, pollinators can discriminate the rewarding and the non-rewarding flowers and visit only the rewarding fresh flowers. Colour change in older flowers and their retention on the plants has been reported in over 200 species belonging to 74 families indicating it to be a common strategy to increase pollination efficiency (Gori 1983, Weiss 1991).

In Dalbergia sissoo, an important timber yielding species, apart from demonstrating that honey bee, Apis dorsata as the predominant pollinator, unlike earlier reports indicating the species to be an inbreeder, it was shown to be self-incompatible and a predominant outbreeder (Menon 1993). Oil palm (Elaeis guineensis) is an important oil-yielding crop native to Africa, but introduced to India 
Fig. 6. Pollination by bees and birds (A) Apis dorsata pollinating the flowers of Bael (Aegle marmelos). (B) Bulbuls pollinating flowers of Tecomella undulata.
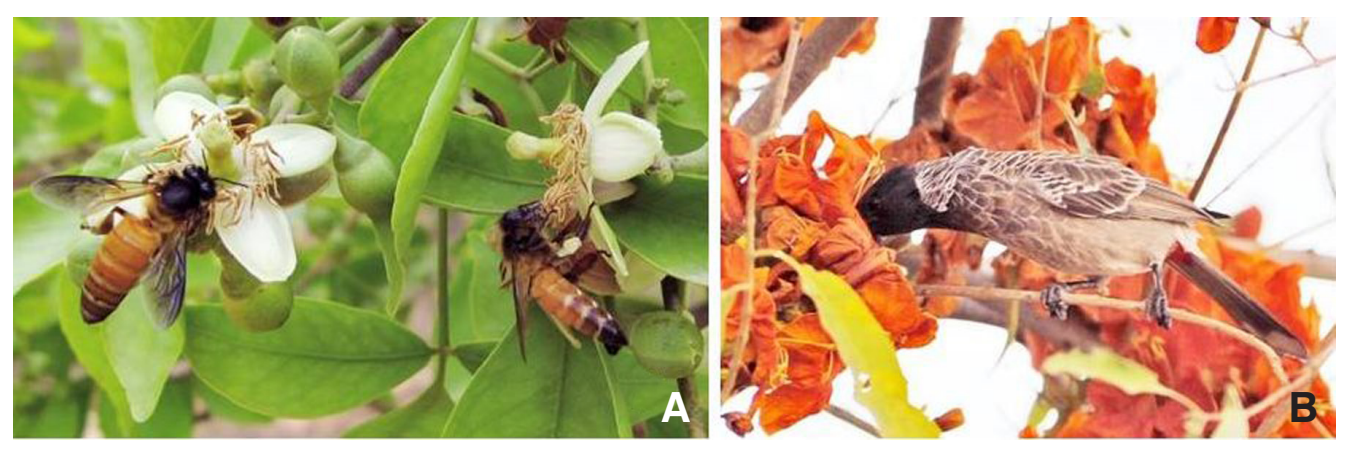

to exploit the species for oil production. In its native country, oil palm is pollinated partly by wind and partly by weevils (Elaeidobius kamerunicus). No information was available on the reproductive biology of oil palm in India. Detailed studies from Delhi School (Tandon et al., 2001a) showed that the style in this species is typically hollow with a layer of canal cells with a thick pectinaceous inner tangential wall. One of the interesting features reported is that the canal cells at the base of the style are papillate and loosely fill the stylar canal. Around the plantations located around Shimoga and Bhadravati areas in Karnataka, weevils were found to be abundant and the pollination was adequate.

Volvulopsis nummularium (Convolvulaceae) is a prostrate rainy season weed in North India. Apis cerana is the effective pollinator (Sarma et al., 2007). Although snails have been observed on the flowers of several species, they are generally considered as destructive to flowers. However, a meticulous study from Delhi School demonstrated that, one of the terrestrial snails, Lamellaxis gracile, was an effective pollinator (malacophily) of this species. Interestingly, snails turned out to be exclusive pollinators on rainy days when the bees are not active. So far, this is the only evidence of malacophily from India.

Many of the floral visitors harvest floral nectar without bringing about pollination. Nectar robbing is quite common in many plant species which bear tubular flowers (Maloof and Inouye 2000, Irwin et al., 2010). In general, the robbers tend to reduce the pollination efficacy of the plant species, as the robbed flowers may dissuade the legitimate pollinators from visiting the plants. Thus, nectar robbing usually has a negative impact on the fitness of plants. However, in recent years, some investigators have shown that nectar robbing can also improve the fitness of the plant species (Navarro 2000, Richardson 2004). Singh et al., (2014) from Delhi School have shown that nectar robbing can have a positive influence, in Tecomella undulata(Bignoniaceae). The study carried out in Rajasthan showed that the trumpet-shaped flowers are robbed of its nectar by purple sunbirds that visit a couple of hours before the arrival of its legitimate pollinators, the bulbuls (Pycnonotus cafer and $P$. leucotis). As the nectar requirement of the pollinators is more than what is left by the robbers in a flower, the pollinators tend to visit more flowers and cover a greater number of trees in their foraging bout than under unrobbed floral conditions. The obligate self-incompatible trees in the population are benefitted with increased pollen flow among the trees due to robbing-induced enhanced foraging by the pollinators.

Neem (Azadirachta indica) and Bael (Aegle marmelos) are two of the economically important trees species from India. Our studies on these two trees have shown that both the species are self-incompatible and rely on Apis spp. for pollination success (Fig. 6, Vikas and Tandon 2011, Bhardwaj and Tandon 2013). In Bael, because of geitonogamy (pollination between the flowers of the same plant), nearly $40 \%$ of the fruits are aborted at different stages of development, thereby bringing down the natural fruit-set. The fruits formed initially tend to attain commercially appealing large size, as they become the sink of resources and the later formed fruits tend to remain small because of the limitation of available resources in the trees.

Oroxylum indicum (Bignoniaceae) is also a self-incompatible tree species in which pollen tube inhibition is in the ovarian region (late-acting self-incompatibility, LSI). Oroxylum indicum is pollinated nocturnally by bats (chiropterophily). This is perhaps the first comprehensive study from the country which demonstrated the mechanism of bat pollination. The trees have a wide range of distribution in the Orient, and specialized for bat-pollination; however, the bat species may differ in different parts of the region. For example, in Malaysia, the pollinator bat species is Eonycteris spelaea, whereas under Indian conditions it is Cynopterus sphinx (Vikas etal., 2009). One of the essential requirements for pollination success in this tree species is a bat of suitable size and weight, the pollen laden snout of which should match perfectly with the opened flower for pollen transfer.

Wrightia tomentosa (Apocynacaeae) is another nocturnally pollinated and commercially over-exploited tree species. Studies carried out by our group in a natural population in Rajasthan have shown that the species depends on moths for pollination success (Barman et al., 2018). Although the flower is structurally adapted for selfing, moths can effectively bring about cross-pollination. As the species is self-compatible, geitonogamy is also effective in the species. The study showed that the settling moths (Parotis marginata, Pygospila tyres, Ericeia sp., Hypopyra sp) are effective in geitnogamy, while the hawkmoths (Theretra silhetensis, Macroglossum trochilus, Cephanodes hylus, Deilephila elpenor) in outcrossing. Parent-progeny analysis carried out by employing ALFP markers indicated that nearly $70 \%$ of the seeds in fruit were outcrossed. The study, thus clearly demonstrated the incidence of mixed-mating in the tree species.

Our group at the Delhi School has been investigating the Himalayan Seabuckthorn (Hippophae rhamnoides, Elaeagnaceae) for almost a decade in the Leh-Ladkah region, and has generated a vast amount of information on its reproductive strategy. The sexuality of the plants is subdioecious. Besides the occurrence of male and female plants, some plants in the population bear male, female and bisexual flowers (Mangla et al., 2013, 2018). This condition is believed to be transient between cosexuality and complete dioecy. 
The plants are pollinated abiotically by wind (anemophily) (Mangla and Tandon 2014). The usual transmitting tissue tract is missing and the pollen tube enters through an external pore located at the base of the pistil to fertilize the solitary ovule, located inside the ovarian locule. One of the interesting field observations that an isolated patch of female plants can also set fruits gregariously, led to a detailed investigation which established that the species is a facultative apomict (Mangla et al., 2015). Such a condition serves as mean of reproductive assurance (Shivanna 2015a).

Professor Shivanna, following his superannuation from the University of Delhi in 2002, joined Ashoka Trust for Research in Ecology and the Environment (ATREE), Bengaluru as INSA Senior Scientist and later as INSA Honorary Scientist and has continued work on pollination strategies of over 25 endemic and economically important species of the Western Ghats (Sharma et al., 2008, 2010, Sinu et al., 2011, Kuriakose et al., 2009, 2018 a, b, Shivanna 2014, 2015b).

\section{Aquatic species}

Although Indian flora is rich in aquatic species, there were hardly any studies on their pollination biology. One of the reasons for this seems to be the difficulty in carrying out such studies especially on submerged aquatics. Apart from classical studies by Kausik (1939) on pollination biology of Vallisnaria spiralis, all other studies on this interesting group of plants have been largely carried out at the Delhi School. Utricularia inflexa is an insectivorous plant and its nitrogenous requirements were believed to be fulfilled by insects caught in their bladders. However, in vitro studies demonstrated that it can complete its life cycle by utilizing only inorganic nitrogen (Doreswamy and Mohan Ram 1969, Khosla et al., 1998). Pollination biology of this species was studied on plants growing in their natural habitat as well as those grown in vitro. The inflorescence is borne above the water level. The flowers are cleistogamous (do not open). The stigma is bilipped, bears ECM as in other plants and forms an irregular funnel leading to a hollow style. In mature flowers, the lower lobe of the stigma becomes reflexed thus bringing the stigmatic surface in contact with the dehisced anthers and effecting autogamous pollination. Pollination efficacy is $97 \%$ in natural habitat and $100 \%$ in cultured plants.

In two other species of Uticularia, U. praeterita and U. babui, distributed near Kohlapur, however, the flowers are not cleistogamous; they open and allow insect pollination (Chaudhary et al., 2018). Both the species achieve self-pollination through spontaneous autogamy when the opportunity for outcrossing is lost due to the absence of pollinators. Autogamy occurs due to the loss of 'herkogamy' (placement of anthers and stigma at different levels in a flower) i.e by the elongation of anther filaments until the anthers reach the level of the receptive stigma. Such a 'delayed-selfing' is believed to have evolved in plants occupying pollinator-limited environments.

Ceratophyllum is another aquatic plant, and pollination studies were carried out on in vitroraised plants of two species (Sehgal and Mohan Ram 1981). In both the species, mature stamens abscise from the male flowers and rise to the surface of the liquid medium. Pollen grains germinate inside the anthers (in situ pollen germination). Following anther dehiscence the germinated pollen grains are released on to the surface of the liquid culture medium; they gradually sink through the medium and come in contact with the stigma of submerged female flowers, thus bringing about pollination.

The family Podostemaceae, represented by about 48 genera and 270 species, is one of the most interesting families of aquatic plants showing unusual features in morphology, ecology and embryology. The plant body of these species is thalloid without differentiation into roots, stem and leaves. They grow in tropical and subtropical rivers or under waterfalls firmly attached to the surface of rocks and boulders by means of rhizoids. The members lack many embryological features such as antipodal cells in the female gametophyte, double fertilization and endosperm formation, typical features of other flowering plants. India has 10 genera and 28 species and most of them are endemic, and confined to Kerala and Karnataka (Khanduri et al., 2015). So far, pollination biology of six Indian taxa of this family has been studied - Polypleurum stylosum (Khosla et al., 2000), Griffithella hookeriana (Khosla et al., 2001), Indotristicha ramosissima (Khosla and Sehgal 2009), Hydrobryopsis sessilis (Sehgal et al., 2009), Willisia arekaliana (Khanduri et al., 2014) and Zeylanidium lichenoides (Chaudhary et. al., 2014). The flowers are tiny in all the species and show autogamy. This is largely because of the synchronization of anther dehiscence and stigma receptivity and proximity of the anthers to the stigma. In some species, pollen grains germinate inside the anthers and germinated pollen grains come in contact with the receptive surface of the stigma thus effecting pollination. As a result of autogamy, there is no pollination limitation and the fruit set is very high (almost 100\%). Allogamy has not been reported from any of the Indian taxa so far.

The Delhi School made attempts, for the first time, to investigate the possible cause of lack of double fertilization in two of the podostemads, Dalzellia indica (Sehgal et al., 2011) and Zeylanidium lichenoides (Chaudhary et al., 2014). These studies clearly showed the differentiation of the egg and the central cell in the female gametophyte and the formation of the two male gametes in the pollen tubes. However, the central cell degenerates before the arrival of the pollen tube, and consequently only syngamy (fusion of one of the male gametes with the egg cell) occurs. Our group has also looked into the role of polycomb genes in Podostemaceae, which are known to play a crucial role in seed development. We isolated, characterized and looked into the expression pattern of homologs of Fertilization Independent Endosperm (FIE) in two species, Zeylanidium olivaceum (ZoFIE) and Polypleurum stylosum (PsFIE) (Khanduri et al., 2015, 2016). Expression studies revealed that transcripts of the homologs were present only in the vegetative tissue and seedlings. This indicates that in the absence of double fertilization and endosperm formation, the expression of FIS complex genes perhaps are obliterated in Podostemaceae.

\section{Ovule pollination and fertilization}

One of the basic requirements of sexual reproduction in any organism is that the male and female gametes involved in fertilization should belong to the same species. This is imperative for the maintenance of species integrity. In most of the organisms this is achieved by the ability of the male and female gametes of the same species to recognize each other and fuse. When the gametes of different species come together, they cannot establish recognition and thus cannot fuse. Fertilization in flowering plants is more complex when compared to other groups of plants. It occurs in the embryo sac (female gametophyte) located deep inside the ovule, which in 
turn is covered by the ovary. Extensive studies carried out since 1940 s on self-and interspecific incompatibility have shown that the pistil screens the pollen grains and only the pollen tubes from the right type of pollen are allowed to reach the ovule; Incompatible pollen/pollen tubes are inhibited in the pistil. However, these studies could not tell whether the ovule/egg still has the ability to recognize compatible gametes and reject incompatible gametes. One of the approaches to understand this problem is to eliminate the stigma, style and ovary wall altogether and bring the pollen grains in direct contact with the ovules. This was achieved for the first time in Delhi School in 1960s in Papaver somniferum (Kanta et al.1962). Pollen grains were brought in direct contact with the ovules through culture of isolated ovules and pollen grains together on a nutrient medium. Pollen germination, pollen tube entry into the ovules and double fertilization proceeded normally, and fertilized ovules developed into viable seeds. Subsequent studies by other investigators from Delhi School showed that though this approach worked in a few systems (Rangaswamy and Shivanna 1969), it was not effective in several others largely due to the failure of the pollen tubes to enter cultured ovules. Eventually the technique of ovule pollination was modified to achieve success. Instead of culturing isolated groups of ovules and pollen grains together on the medium, the whole placenta intact along with the ovules was cultured by inserting only the pedicel into the medium. The ovule mass was pollinated with the pollen (Rangaswamy and Shivanna 1967, Zenkteler 1967). This modified technique, termed placental pollination, prevented the injury to and wetting of the ovules and pollen grains, and at the same time brought the pollen in direct contact with the ovules. Using this technique, it was possible to achieve fertilization and seed development in vitro(Fig. 7). More importantly, this technique was effective in overcoming self- incompatibility (inability of plants to set seeds upon self-pollination) in Petunia (Rangaswamy and Shivanna 1967) as well as interspecific incompatibility between Melandrium and related species (Zenkteler 1967). Based on these studies, Shivanna hypothesized that in flowering plants, the function of recognition of male gametes has been transferred from the egg/ovule to the pistillate tissue and the ovules seem to accept any male gamete that reaches the embryo sac (Shivanna 1979, 2003, Shivanna and Johri 1985). The technique of placental
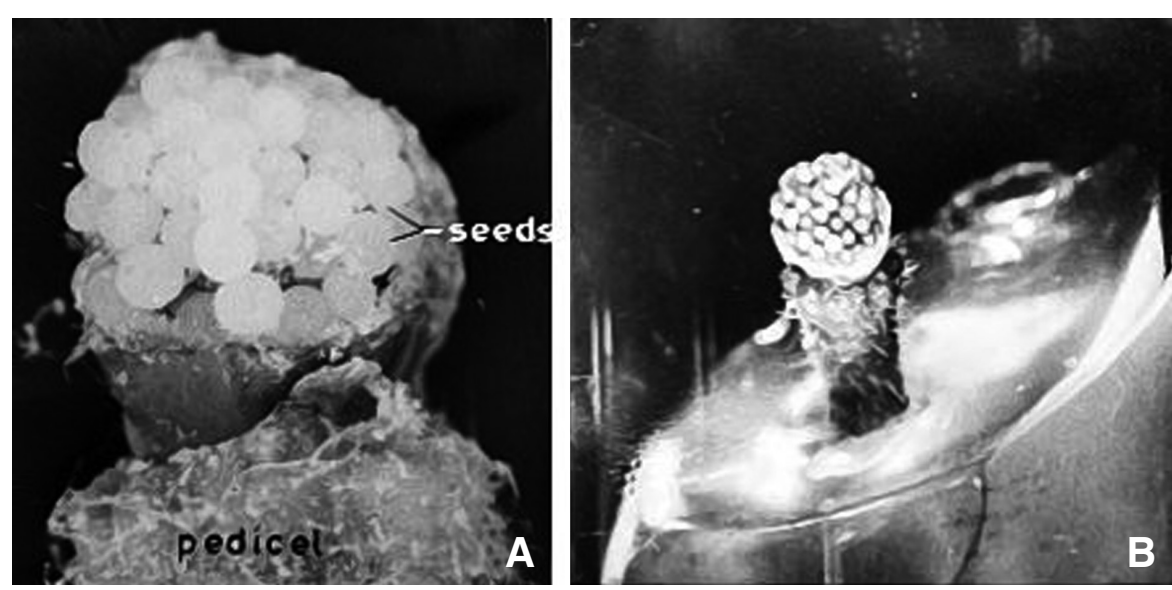

Fig. 7. Ovule pollination in Petunia axillaris. (A) Fourteen-day-old ovule pollinated culture to show young seeds. (B) Twenty one-day-old ovule pollinated culture to show the development of mature seeds. pollination has been used by other investigators to understand many fundamental aspects of seed development (Balatkova and Tupy 1972, Balatkova et al., 1976) and to overcome inter-specific incompatibility in Nicotiana and Brassica (Zenkteler 1990, Zenkteler and Bagniewska-Zadworna 2001).

It was known that pollination stimulus is transmitted to the ovary before the pollen tubes reach the ovary and activates the ovary to receive pollen tubes (see Shivanna 2003). However, there was no way of testing whether self-pollination stimulus in self-incompatible species also reaches the ovules and enables them to prevent fertilization even when self-pollen tubes reach the ovary. A technique of two-site pollination (on the stigma and on the placenta) in vitro was devised to study possible transmission of the self-incompatible stimulus. Detailed experimental studies clearly showed that self-incompatibility inhibition is purely resident to the pistil; the stimulus does not get transmitted to the ovary to inactivate ovules to receive self-pollen tubes (Rangaswamy and Shivanna 1971); at the level of the ovules, both self- and cross-pollen grains are equally effective in achieving fertilization even in pistils in which the stigma was pollinated with self-pollen, much before ovule pollination.

Inaccessibility of male and female gametes during fertilization has been a major limitation in understanding and manipulating fertilization. One of the objectives of embryologists has been to achieve in vitro fertilization as has been done in a number of animals including humans and a few lower plants. The progress on these lines in flowering plants had to wait until protoplast technology became available during 1970s and 80s. Remarkable progress in protoplast technology stimulated work on isolation of male and female gametes in different plant species. Isolation of male gametes from 3-celled pollen grains was straight forward; it was achieved by disrupting pollen grains to release gametes followed by suitable centrifugation. However, it was difficult to isolate male gametes in 2-celled pollen systems as the gametes are formed during pollen tube growth in the style. Shivanna from Delhi School, working at Melbourne University was the first to isolate male gametes from a 2-celled pollen of Gladiolus by using a semi-vitro technique (Shivanna et al., 1987). Subsequently, the technique has been used by others to isolate male gametes from other 2-celled pollen systems (Tian and Russell 1997, Qiu et al., 2004).

Simultaneously, progress was made in isolating female gametes also in a number of species. The first success of in vitro fertilization was reported in maize by a German group (Kranz and Lorez 1994). They could rise normal fertile plants from in vitro fertilized zygote. A number of studies are being made to understand fundamental aspects of double fertilization using in vitro fertilization and considerable progress has been made (Okamoto and Kranz 2005, Uchiumi et al., 2007, Ohnishi et al., 2014). One of the interesting outcomes has been the confirmation of the earlier concept (Shivanna 1979) about the inability of the egg to reject incompatible male gametes; it seems to accept male gametes coming from homospecific as well as heterospecific species (Kranz and Dresselhaus 1969). 


\section{Conclusions}

A brief account of the studies carried out at the Delhi School on developmental biology of dispersed pollen given above amply indicates the extent of new knowledge generated in this field. Apart from their importance in understanding pollen biology, these studies have practical applications especially in pollen storage, conservation of endemic and endangered species and in sustainable utilization of economically important species. In recent years another dimension to the developmental biology of pollen has been added at Delhi School by integrating the techniques of molecular biology and genetics. This is bound to generate comprehensive knowledge relevant to a better understanding of pollen function and their manipulation.

\section{Acknowledgements}

We dedicate this review with gratitude to the memory of late Professor H.Y. Mohan Ram, who not only collaborated with us in considerable part of the work reported here, but also was a constant source of encouragement to both of us.

\section{References}

BALATKOVA V, HRABETOVA E, TUPY J (1976). The effect of sugar nutrition of in vitro pollinated placentae on seed set and dormancy in Nicotiana tabacum L. Experientia 32: 1255-1256.

BALATKOVA V, TUPY J (1972). Some factors affecting the seed set after in vitro pollination of excised placentae of Nicotiana tabacum I. Biol Plant 14: 82-88.

BARMAN C, SINGH VK, DAS S, TANDON R (2018). Floral contrivances confer strong influence on moth-pollinated and self-compatible Wrightia tomentosa (Apocynaceae) to elicit mixed-mating. Plant Biol 20: 546-554.

BHARDWAJ V, TANDON R (2013). Self-incompatibility and post-fertilization maternal regulation causes low fecundity in Aegle marmelos (Rutaceae). Bot J Linn Soc 172: $572-585$.

BIESMEIJER JC, ROBERTS JC, REEMER M et al., (2006) Parallel declines in pollinators and insect-pollinated plants in Britain and the Netherlands. Science 313: 351-354.

BURKLE LA, MARLIN LA, KNIGHT TM (2013). Plant-pollinator interactions over 120 years: Loss of species, co-occurrence, and function. Science 339: 1611-1615.

CEBALLOS G et al.,2017). Biological annihilation via the ongoing sixth mass extinction signalled by vertebrate population losses and declines. Proc Natl Acad Sci USA 114: doi:10.1073/pnas.1704949114

CHAUDHARY A, KHANDURI P, TANDON R, UNIYAL P L, MOHAN RAM H Y 2014. Central cell degeneration leads to three-celled female gametophyte in Zeylanidium lichenoides Engl., (Podostemaceae). S Afr J Bot 91: 99-106.

CHAUDHARY A, YADAV SR, TANDON R (2018). Delayed selfing ensures reproductive assurance in Utricularia praeterita and Utricularia babui in Western Ghats. J Plant Res 131:599-610.

CHAUDHURY R, SHIVANNA KR (1986). Studies on pollen storage in Pennisetum typhoides. Phytomorphology 36: 211-218.

CHAUDHURY R, SHIVANNA KR (1987). Differential responses of Pennisetum and Secale pollen. Phytomorphology 37: 181-185.

DAFNI A, HESSE M, PACINI E (EDS) (2000). Pollen and pollination. Springer Wissen, New York, NY

DAVIS M, FAURBY S, SVENNING J-C (2018). Mammal diversity will take millions of years to recover from the current biodiversity crisis. Proc Natl Acad Sci USA doi.org/10.1073/pnas.1804906115

DORESWAMY R, MOHAN RAM HY (1969) Studies on the growth and flowering of axenic cultures of insectivorous plants. 1. Seed germination and establishment of cultures of Utricularia inflexa. Phytomorphology 19: 363-371.

FAEGRI K, VAN DER PIJL L (1979). The principles of pollination ecology. $3^{\text {rd }}$ Ed. Pergamon Press, Oxford, UK

GHOSHS, SHIVANNAKR(1982). Anatomical and cytochemical studies on the stigma and style in some legumes. Bot Gaz 143: 311-318.

GHOSHS, SHIVANNAKR (1982). RNA and protein synthesis during pollen germination and tube growth in Zephyranthes. Plant Physiol Biochem 10: 1-10.

GHOSH S, SHIVANNA KR (1984). Structure and cytochemistry of the stigma and pollen-pistil interaction in Zephyranthes. Ann Bot 53: 91-105.

GORIDF (1983). Post-pollination phenomena and adaptive floral changes. In Handbook of experimental pollination biology. CE Jones and RJ Little (eds), van Nostrand Reinhold Company Inc. New York, PP 31-49.

GUHA S, MAHESHWARI SC (1964). In vitro production of embryos from anthers of Datura. Nature 204: 497.

GUHA S, MAHESHWARI SC (1966). Cell division and differentiation of embryos in the pollen grains of Datura in vitro. Nature 212: 97-98.

GUPTA PROMILA, SHIVANNA KR, MOHAN RAM HY (1996). Apomixis and polyembryony in guggul plants, Commiphora wightii. Ann Bot 78: 67-72.

GUPTA PROMILA, SHIVANNA KR, MOHAN RAM HY (1998). Pollen-pistil interaction in a non-pseudogamous apomict, Commiphora wightii. Ann Bot 81: 589-594.

HERRERA CM, PELLMYR O (EDS) (2002). Plant-animal interaction: An evolutionary approach. Blackwell Publ, Oxford, UK.

HESLOP-HARRISON J (1975). The Croonian Lecture 1974. The physiology of the pollen grain surface. Proc $R$ Soc Lond, Ser B 190: 275-299.

HESLOP-HARRISON J, HESLOP-HARRISON Y, SHIVANNA KR (1984). The evaluation of pollen quality and a further appraisal of the fluorochromatic (FCR) test procedure. Theor Appl Genet 67: 367-375.

HESLOP-HARRISON J, KNOX RB, HESLOP-HARRISON Y(1974). Pollen wall proteins: exine-held fractions associated with the incompatibility response in Cruciferae. Theor Appl Genet 44: 133-137.

HESLOP-HARRISON Y, SHIVANNA KR (1977). The receptive surface of the angiosperm stigmas. Ann Bot 41: 1233-1258.

HIGASHIYAMA T, HAMAMURA Y (2008). Gametophytic pollen tube guidance. Sex Plant Repro. 21: 17-26.

HODGKIN T (1983). A medium for germinating Brassica pollen in vitro. Cruciferae Newslett 8: 62

HOEKSTRAFA, BRUINSMAJ (1979). Protein synthesis in binucleate and trinucleate pollen and its relationship to tube emergence and growth. Planta 146: 559-566.

HOEKSTRAFA, BRUINSMAJ (1980). Control of respiration of binucleate and trinucleate pollen under humid conditions. Physiol Plant 48: 71-77.

HOEKSTRA FA, CROWE LM, BRUINSMA J (1989). Differential desiccation sensitivity of corn and Pennisetum pollen linked to their sucrose content. Plant Cell Environ 12: 83-91.

HOLDEN C (2006) Report warns of looming pollination crisis in North America Science 314: 397

IPBES (2016) Summary for policymakers of the assessment report of the Intergovernmental Science-Policy Platform on Biodiversity and Ecosystem Services on pollinators, pollination and food production. (EdPG Potts et al.). IPBES Secretariat, Bonn, Germany. 36 pages.

IRWIN RE, BRONSTEIN JL, MANSON JS, RICHARDSON L (2010). Nectar robbing: Ecological and evolutionary perspectives. Ann Rev Ecol, Evol Syst 41: 271-292.

JAINA, SHIVANNAKR(1987a). Storage of pollen grains in organic solvents: Effects of solvents on pollen viability and membrane integrity. J Plant Physiol 132: 499-502.

JAIN A, SHIVANNA KR (1987b). Storage of pollen grains in organic solvents: Effect of organic solvents on leaching of phospholipids and its relationship to pollen viability. Ann Bot 61: 325-330.

JAIN A, SHIVANNA KR (1989). Loss of viability during storage is associated with changes in membrane phospholipids. Phytochemistry 28: 999-1002.

JAIN A, SHIVANNA KR (1990). Storage of pollen grains of Crotalaria retusa in oils Sex Plant Repro 3: 225-227.

JOHRI BM, VASIL IK (1961). Physiology of pollen. Bot Rev 27: 325-381.

JOHRI MM (1966a). The style, stigma and pollen tube I. Some taxa of the Liliaceae and Triliaceae. Phytomorphology 16: 92-109.

JOHRI MM (1966b). The style, stigma and pollen tube II. Some taxa of the Amaryllidaceae. Phytomorphology 16: 142-157.

KANTA K, RANGASWAMY NS, MAHESHWARI P (1962). Test-tube fertilization in a flowering plant. Nature 194. 1214-1217. 
KAUSIK SB (1939). Pollination and its influences on the behaviour of the pistillate flower in Vallisneria spiralis. Am J Bot 26: 207-211.

KAWASHIMA T, BERGER F (2011). Green love talks; cell-cell communication during double fertilization in flowering plants. AoB Plants plr015, https://doi.org/10.1093/ aobpla/plr015

KEARNS CA, INOUYE DW (1993). Techniques for pollination biologists. Univ Press, Colorado, CO.

KHANDURIP, CHAUDHARYA, UNIYALPL, TANDONR(2014). Reproductive biology of Willisia arekaliana (Podostemaceae), a freshwater endemic species of India. Aquatic Bot 119: 57-65.

KHANDURI P, SHARMA R, BHAT V, TANDON R (2016). Isolation, expression and evolution of FERTILIZATION INDEPENDENT ENDOSPERM homologs in Podostemaceae. J Plant Res 129: 241-250.

KHANDURI P, TANDON R, UNIYAL P L, BHAT V, PANDEY A K. (2015). Comparative morphology and molecular systematics of Indian Podostemaceae. Plant Syst Evol. 301: 861-882. doi 10.1007/s00606-014-1121-x.

KHOSLA C, MOHAN RAM HY (1993). Morphology of flower, fruit and seed in Polypleurum stylosum. Aquatic Bot 46: 125-128.

KHOSLA C, SEHGAL A (2009). Pollination biology of Indotristicha ramosissima (Podostemaceae: Tristichoideae). Aquatic Bot 91: 51-56.

KHOSLA C, SHIVANNA KR, MOHAN RAM HY (2000) Reproductive biology of Polypleurum stylosum (Podostemaceae) Aquatic Bot 67: 143-154.

KHOSLA C, SHIVANNA KR, MOHAN RAM HY (2001). Cleistogamy in Griffithella hookeriana (Podostemaceae). South African J Bot 67: 24-328

KHOSLA C, SHIVANNA KR, MOHAN RAM HY 1998. Pollination in the aquatic insectivore Utricularia inflexa var. stellaris. Phytomorphology 48: 417-425.

KNOX RB, HESLOP-HARRISON J (1969). Cytochemical localization of enzymes in the wall of the pollen grains. Nature 223: 92-94.

KNOX RB, WILLING RR, ASHFORD AE (1975). Pollen wall proteins: role as recognition substances in interspecific incompatibility in poplars. Nature 237: 381-383.

KONOR RN, LINSKENS HF (1966a). The morphology and anatomy of the stigma of Petunia hybrida. Planta 71: 356-371.

KONOR RN, LINSKENS HF (1966b). Physiology and biochemistry of stigmatic fluid in Petunia hybrida. Planta 71: 372-387.

KRANZ E, DRESSELHAUS T (1996). The in vitro fertilization with isolated higher plant gametes. Trends Plant Sci 1: 82-89.

KRANZ E, LORZ H (1994). In vitro fertilization with isolated single gametes results in zygotic embryogenesis. Plant Cell 5: 736-746.

KURIAKOSE G, SINU PA, SHIVANNAKR (2009). Domestication of Cardamom (Elettaria cardamomum) in Western Ghats, India: Divergence in productive traits and a shift in major pollinators. Ann Bot 103: 727-733.

KURIAKOSE G, SINU PA, SHIVANNA KR (2018a). Ant pollination in Syzygium occidentale, an endemic tree species of tropical rain forests of the Western Ghats, India. Arthropod-Plant Interaction 12: 647-655.

KURIAKOSE G, SINU PA, SHIVANNA KR (2018b). Floral traits predict pollination syndrome in Syzygium species: a study on four endemic species of the Western Ghats, India. Australian J Bot 66: 575-582.

LAKSHMI KV, SHIVANNA KR (1984). Structure and cytochemistry of the pistil in Arachis hypogaea. Proc Indian Acad Sci 95B: 357-363.

MAHESHWARI SC, TYAGI AK, MALHOTRA K, SOPORY SK (1980). Induction of haploidy from pollen grains in angiosperms - the current status. Theor Appl Genet 58: 193-206.

MALOOF JE, INOUYE DW (2000). Are nectar robbers cheaters or mutualists? Ecology 81: 2651-2661.

MALTI, SHIVANNA KR (1984). Pollen-pistil interaction in chickpea. Intl Chickpea Newsletter 9: 10-11.

MALTI, SHIVANNA KR (1984). Structure and cytochemistry of the pistil in Crotalaria retusa L. Proc Indian Natl Sci Acad B50: 92-102.

MANGLA Y, TANDON R, GOEL S, RAINA S N (2013). Structural organization of gynoecium and pollen tube path in Himalayan Seabuckthorn, Hippophae rhamnoides (Elaeagnaceae) AoB PLANTS 5: plt015. doi:10.1093/aobpla/plt015.

MANGLAY, CHAUDHARY M, GUPTA H, THAKUR R, GOELS, RAINASN, TANDON $R$ (2015). Facultative apomixis and development of fruit in a deciduous shrub with medicinal and nutritional uses. AoB Plants 7: plv098. doi: 10.1093/aobpla/plv098.
MANGLA Y, DAS K, BALI S, AMBREEN H, RAINAS N, TANDON R, GOEL S (2019). Occurrence of subdioecy and scarcity of gender-specific markers reveal an ongoing transition to dioecy in Himalayan seabuckthorn (Hippophae rhamnoides ssp. turkestanica). Heredity 122: 120-132.

MANGLA Y, TANDON R (2014). Pollination ecology of Himalayan sea buckthorn (Hippophae rhamnoides). Curr Sci 106: 1731-1735.

MASCARENHAS JP (1975). The biochemistry of angiosperm pollen development. Bot Rev 41: 259-314.

MASCARENHAS JP (1993). Molecular mechanism of pollen tube growth and differentiation. Plant Cell 5: 1303-1314.

MATHUR G, MOHAN RAM HY (1978). Significance of petal colour in thrips-pollianted Lantana camara L. Ann Bot 42: 1473-1476.

MENONS, SHIVANNAKR, MOHANRAM HY (1993). Pollination ecology of Dalbergia sisso - an important Indian tree legume. In: Pollination in tropics (Eds. GK Veeresh, R Uma Shaanker and KN Ganeshaiah). Intl Union of the Study of Social Insects (IUSSI), Indian Chapter, Bangalore, pp. 148-149.

MISHRA R, SHIVANNA KR (1982). Efficacy of some organic solvents for prolonging viability of some leguminous pollen. Euphytica 31: 991-996.

MIZUTA Y, HIGASHIYAMA T (2018). Chemical signalling of pollen tube guidance at a glance. J Cell Sci 131: jcs208447

MOHAN RAM HY, MATHUR G (1984). Flower Colour Changes in Lantana camara $J$ Experimental Bot 35: 1656-1662.

MULCAHY DL (1979). Rise of the angiosperms: a genecological factor. Science 206: 20-23.

NAIR MNB, SHIVANNA KR, MOHAN RAM HY (1995). Ethephon enhances karaya gum yield and wound healing responses: Preliminary report. Curr Sci69: 809-810.

NAVARRO L (2000). Pollination ecology of Anthyllis vulneraria subsp. vulgaris (Fabaceae): nectar robbers as pollinators. Am J Bot 87: 980-985.

OHNISHIY, HOSHINOY, OKAMOTOT(2014). Dynamics of male and female chromatin during karyogamy in rice zygotes. Plant Physiol 165: 1533-1543.

OKAMOTO T, KRANZE (2005). In vitro fertilization - a tool to dissect cell specification from higher plant zygotes. Curr Sci 89: 1861-1869.

PRIESTLEY DA (1986). Seed ageing: Implications for seed storage and persistence in the soil. Comstock, Ithaca, London.

QIU Y-L, YANG Y-H, ZHANG S-Q, TIAN H-Q (2004). Isolation of two populations of sperm cells from the pollen tube of tobacco. Acta Bot Sinica 46: 719-723.

RANGASWAMY NS, SHIVANNA KR (1967). Induction of gamete compatibility and seed formation in axenic cultures of a diploid self-incompatible species of Petunia. Nature 216: 937-939.

RANGASWAMY NS, SHIVANNA KR (1969). Test tube fertilization in Dicranostigma franchetianum (Prain) Fedde. Curr Sci 38: 257-259.

RANGASWAMYNS, SHIVANNAKR(1971). Overcoming self-incompatibility in Petunia axillaris (Lam.) B.S.P. III. Two-site pollination. Phytomorphology 21: 284-289.

RAO GU, JAIN A, SHIVANNA KR (1992). Effects of high temperature stress on Brassica pollen: Viability, germination and ability to set fruits and seeds. Ann Bot 69: 193-198.

RAO GU, SAWHNEY VK, SHIVANNAKR (1995). Thermotolerance of pollen of Petunia and Nicotiana. Curr Sci 69: 809-810.

READ SM, CLARKE AE, BACIC A (1993). Stimulation of growth of cultured Nicotiana tabacum W 38 pollen tubes by polyethylene glycol and $\mathrm{CU}_{(\mathrm{II})}$ salts. Protoplasma 177: $1-14$.

RICHARDSON SC (2004). Are nectar-robbers mutualists or antagonists? Oecologia 139: 246-254.

ROUBIK DW (Ed) (1995). Pollination of cultivated plants in the tropics. FAO Agriculture Service Bull.

SARMA K, TANDON R, SHIVANNA KR, MOHAN RAM HY (2007). Snail-pollination in Volvulopsis nummularium. Curr Sci 93: 826-831

SEHGAL A, MOHAN RAM HY (1981). Comparative developmental morphology of two populations of Ceratophyllum L. (Ceratophyllaceae) and their taxonomy. Bot $J$ Linnean Soc 82: 343-356.

SEHGAL A, SETHI M, MOHAN RAM HY (2009). Development of the floral shoot and pre-anthesis cleistogamy in Hydrobryopsis sessilis (Podostemaceae). Bot $J$ Linn Soc 159: 229-236.

SEHGALA, KHURANAJP, SETHI M, HUSSAINA(2011). Occurrence of unique three 
celled megagametophyte and single fertilization in an aquatic angiosperm - Dalzellia zeylanica (Podostemaceae-Tristichoideae). Sex Plant Repr 24: 199-210.

SHARMA M V, KURIAKOSE G, SHIVANNA KR (2008). Reproductive strategies of Strobilanthes kunthianus, an endemic, semelparous species in southern Western Ghats, India. Bot J Linn Soc 157: 155-163.

SHARMAM V, UMASHAANKER R, VASUDEVAR, SHIVANNAKR (2010). Functional dioecy in Nothapodytes nimmoniana, a distylous species in the Western Ghats. Curr Sci 99:1444-1449.

SHIVANNA KR (1979). Recognition and rejection phenomena during pollen-pistil interaction. Proc Indian Acad Sci 88B: 115-141.

SHIVANNA KR (2003). Pollen biology and biotechnology. Science Publishers, Inc. Enfield, USA

SHIVANNA KR (2014). Reproductive assurance through autogamy in some annual weed species. Proc Natl Acad Sci India B84: 681-687.

SHIVANNAKR(2015a). Reproductive assurance through autogamous self-pollination across diverse sexual and breeding systems. Curr Sci 109: 1255-1263.

SHIVANNA KR (2015b). Pollination strategies of some perennial weed species. Proc Indian Natl Sci Acad 81: 485-492.

SHIVANNA KR (2019). The 'sixth mass extinction crisis' and its impact on flowering plants. In Biodiversity and chemotaxonomy (Ed. KG Ramawat), Springer Nature Switzerland, pp. 15-42.

SHIVANNA KR, CRESTI M (1989). Effects of high humidity and temperature stress on pollen membrane and pollen vigour. Sexual Plant Repro 2: 137-141.

SHIVANNA KR, HESLOP-HARRISON J (1981). Membrane state and pollen viability. Ann Bot 47: 759-770.

SHIVANNA KR, HESLOP-HARRISON J, HESLOP HARRISON Y (1978). Pollenstigma interaction: Bud pollination in the Cruciferae. Acta Bot Neerl 27: 107-119.

SHIVANNAKR, HESLOP-HARRISONY, HESLOP-HARRISON J 1978. Pollen-stigma interaction: Bud pollination in the Cruciferae. Acta Bot Neerl 27: 107-119.

SHIVANNAKR, JAISWAL VS, MOHANRAMHY (1974a). Inhibition of gamete formation by cycloheximide in pollen tubes of Impatiens balsamina. Planta 117: 173-177.

SHIVANNA KR, JAISWAL VS, MOHAN RAM HY (1974b). Effect of cycloheximide in cultured pollen grains of Trigonella foenumgraecum. Plant Science Letters 3: $335-339$

SHIVANNA KR, JOHRI BM (1985). The Angiosperm Pollen: Structure and Function. Wiley Eastern, New Delhi. Reprinted 1989 by John Wiley, USA.

SHIVANNAKR, LINSKENS HF, CRESTI M (1991a). Pollen viability and pollen vigour. Theor Appl Genet 81: 38-42.

SHIVANNA KR, LINSKENS HF, CRESTI M (1991b). Responses of tobacco pollen to high humidity and heat stress: germination in vitro and in vivo. Sex Plant Repro 4:104-109.

SHIVANNAKR, MOHAN RAM HY (2005). Contributions of Panchanan Maheshwari's School to angiosperm embryology through an integrative approach. Curr Sci 89: 1820-1834.

SHIVANNA KR, OWENS SJ (1989). Pollen-ovule interactions (Papilionoideae). In CH Stirton, JLZarucchi eds. Advances in Legume Biology. Monographs in Systematic Biology, Missouri Botanical Garden 29: 157-182.

SHIVANNA KR, RANGASWAMY NS (1992). Pollen biology: A laboratory manual. Springer-Verlag, Berlin.

SHIVANNAKR, SASTRI DC (1981). Stigma-surface esterases and stigma receptivity in some taxa characterized by wet stigma. Ann Bot 47: 53-64.

SHIVANNAKR, SAWHNEY VK(1995). Polyethylene glycol improves the in vitrogrowth of Brassica pollen tubes without loss of germination. J Exptl Bot 46: 1771-1774.

SHIVANNA KR, SAXENA NP, SEETHRAMA NP (1998). An improved medium for in vitro pollen germination and pollen tube growth of chickpea (Cicer aeritinum $\mathrm{L}$.)
Intl Chickpea and Pigeonpea Newslett 4: 28-29.

SHIVANNA KR, TANDON R (2014). Reproductive ecology of flowering plants: $A$ manual. Springer India, New Delhi.

SHIVANNA KR, XU H, TAYLOR P, KNOX RB (1987). Isolation of sperms from pollen tubes of flowering plants during fertilization. Plant Physiol 87: 647-650.

SINGH V, BARMAN C, TANDON R (2014). Nectar robbing positively influences the reproductive success of Tecomella undulata(Bignoniaceae). PlosOne9:e102607.

SINU PA, KURIAKOSE G, SHIVANNA KR (2011). Is the bumblebee (Bombus haemorrhoidalis) the only pollinator of large cardamom in central Himalayas, India? Apidologie 42: 690-695. doi: 10.1007/s13592-011-0065-1

STANLEY RG, LINSKENS H (1974). Pollen: Biology, biochemistry and management. Springer, Berlin

SUNNICHEN VG, MOHANRAM HYSHIVANNAKR (2004). Floral sexuality and breeding system in gum karaya tree, Sterculia urens. Plant Syst Evol 244: 201-218.

SUNNICHEN VG, MOHAN RAM HY SHIVANNA KR (2005) Reproductive biology of Boswellia serrata, the source of salai guggul, an important gum-resin. Bot $J$ Linn Soc 147: 73-82.

SUNNICHEN VG, SHIVANNA KR, MOHAN RAM HY (1998). Micropropagation of gum karaya tree (Sterculia urens Roxb.) through multiple shoot formation and somatic embryogenesis. Plant Cell reports 17: 951-956.

TANDON R, CHAUDHURY R, SHIVANNA KR (2007). Cryopreservation of oil palm pollen. Curr Sci 92: 182-183.

TANDON R, MANOHARA TN, NIJALINGAPPA BHM, SHIVANNA KR (1999). Polyethylene glycol enhanses in vitro germination and tube growth of oil palm pollen. Indian J Exptl Biol 37: 169-172.

TANDONR, MANOHARATN, NIJALINGAPPABHM, SHIVANNAKR (2001a). Pollination and pollen-pistil interaction in oil palm, Elaeis guineensis. Ann Bot87:831-838.

TANDON R, SHIVANNA KR, MOHAN RAM HY (2001b): Pollination biology and the breeding system of Acacia senegal. Bot J Linnaean Soc 135: 251-262.

TANDON R, SHIVANNA KR, MOHAN RAM HY (2003) Reproductive biology of Butea monosperma (Fabaceae). Ann Bot 92: 715-723.

TIAN HQ, RUSSELL SD (1997). Micromanipulation of male and female gametes of Nicotiana tabacum: 1. Isolation of gametes. Plant Cell Rep 16: 555-560.

UCHIUMI T, UEMURA I, OKAMOTO T (2007). Establishment of an in vitro fertilization system in rice (Oryza sativa L.). Planta 226: 581-589.

VASIL IK, JOHRI MM (1964). The style, stigma and pollen tube 1. Phytomorphology 14: 352-369.

VIKAS, GAUTAM M, TANDON R, MOHAN RAM HY (2009). Pollination biology and breeding system of Oroxylum indicum in Western Himalaya. J Trop Ecol25: 93-96

VIKAS, TANDON R (2011). Reproductive biology of Azadirachta indica, a medicinal tree species of arid-zone. Plant Sp Biol 26: 116-123.

WEISS MR (1991). Floral colour changes as cues for pollinators. Nature 354:227-229

WILLMER P (2011). Pollination and floral ecology. Princeton University Press, Princeton.

ZENKTELER M (1967). Test-tube fertilization of ovules in Melandrium album Mill. with pollen grains of several species of the Caryophyllaceae family. Experientia 23: $775-777$.

ZENKTELER M (1990). In vitro fertilization and wide hybridization in higher plants. Crit Rev Plant Sci 9: 267-279.

ZENKTELER M, BAGNIEWSKA-ZADWORNA A (2001). Distant in vitro pollination of ovules. In: NS Rangaswamy (ed) Trends in Plant Sciences, Phytomorphology (Golden Jubilee Issue. Intl Soc Plant Morphologists, New Delhi). Pp 331-335.

ZHANG H-Q, CROES AF (1982). A new medium for pollen germination in vitro. Acta Bot Neerl 31: 113-119. 


\section{Further Related Reading, published previously in the Int. J. Dev. Biol.}

The role of ion fluxes in polarized cell growth and morphogenesis: the pollen tube as an experimental paradigm Erwan Michard, Filipa Alves and José A. Feijó

Int. J. Dev. Biol. (2009) 53: 1609-1622

https://doi.org/10.1387/ijdb.072296em

Arabidopsis monomeric G-proteins, markers of early and late events in cell differentiation Mariette Bedhomme, Chantal Mathieu, Amada Pulido, Yves Henry and Catherine Bergounioux Int. J. Dev. Biol. (2009) 53: 177-185

https://doi.org/10.1387/ijdb.072488mb

Self-incompatibility systems: barriers to self-fertilization in flowering plants Anne C. Rea and June B. Nasrallah Int. J. Dev. Biol. (2008) 52: 627-636

https://doi.org/10.1387/ijdb.072537ar

Gametophyte interaction and sexual reproduction: how plants make a zygote Leonor C. Boavida, Ana Maria Vieira, Jörg D. Becker and José A. Feijó

Int. J. Dev. Biol. (2005) 49: 615-632

http://www.intjdevbiol.com/web/paper/052023lb

The making of gametes in higher plants

Leonor C. Boavida, Jörg D. Becker and José A. Feijó

Int. J. Dev. Biol. (2005) 49: 595-614

http://www.intjdevbiol.com/web/paper/052019lb

Cellular characterization of key developmental stages for pollen embryogenesis induction P González-Melendi, P S Testillano, G Préstamo, B Fadón and M C Risueño Int. J. Dev. Biol. (1996) 40: S127-S128

http://www.intjdevbiol.com/web/paper/9087727

Dynamics of ribosome biogenesis during the pollen developmental program by in situ localization of nucleolar targets

P S Testillano, P González-Melendi, P Ahmadian, G Préstamo, C G Mena and M C Risueño Int. J. Dev. Biol. (1996) 40: S121-S122

http://www.intjdevbiol.com/web/paper/9087724
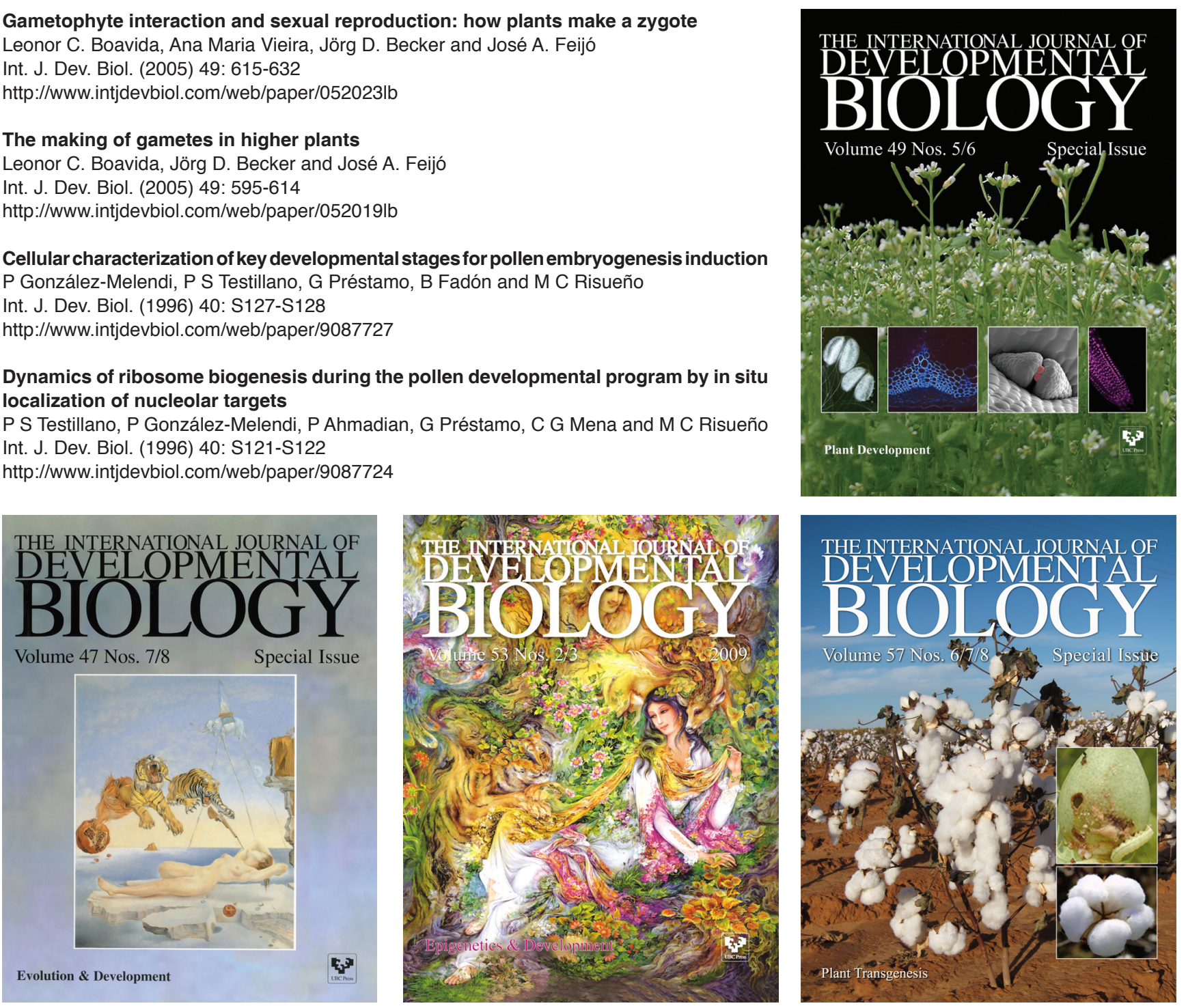